\title{
KAJIAN KONSEP FISHING ECOPORT UNTUK PENGEMBANGAN PELABUHAN PERIKANAN DI INDONESIA
}

\author{
ASSESSMENT OF FISHING ECOPORT CONCEPT FOR DEVELOPMENT OF FISHING PORT \\ IN INDONESIA
}

\author{
La Ode Nurman Mbay ${ }^{1}$, R. Bambang Adhitya Nugraha' ${ }^{1}$ dan Djoko Kusyanto ${ }^{2}$ \\ ${ }^{1}$ Pusat Pengkajian dan Perekayasaan Teknologi Kelautan dan Perikanan-BalitbangKP \\ ${ }^{2}$ Praktisi Pelabuhan Perikanan Indonesia \\ E-mail: mbaynurman@gmail.com
}

Diterima tanggal: 8 Juli 2014, diterima setelah perbaikan: 21 November 2014, disetujui tanggal: 28 November 2014.

\begin{abstract}
ABSTRAK
Mempertahankan mutu produk perikanan adalah hal yang urgent harus dilakukan terkait adanya beberapa kasus penolakan produk ekspor perikanan Indonesia oleh beberapa negara tujuan ekspor seperti Jepang, Uni Eropa dan USA. Kementerian Kelautan dan Perikanan (KKP) menegaskan bahwa keamanan pangan harus dijamin sepanjang rantai produksi berlangsung untuk tetap terus meningkatkan kualitas produk perikanan. Oleh karena itu, KKP perlu mengoptimalkan fungsi pelabuhan perikanan yang merupakan ujung tombak dan prime mover dalam kegiatan pengelolaan dan pemanfaatan sumberdaya ikan dan lingkungannya mulai dari praproduksi, produksi, pengolahan, dan pemasaran. Salah satu konsep yang akan diterapkan oleh KKP adalah fishing ecoport yang mengadop konsep negaranegara Uni Eropa dalam pengelolaan lingkungan pelabuhan untuk peningkatan produksi perikanan yang bermutu dengan berpegang pada prinsip biosecurity dan tracebility produk yang dihasilkan. Pelabuhan perikanan yang menjadi kawasan percontohan penerapan konsep fishing ecoport ini adalah Pelabuhan Perikanan Samudera (PPS) Bitung.
\end{abstract}

Kata kunci: Fishing ecoport, PPS Bitung, Rapert Alert System for Food and Feed (RASFF)

\section{ABSTRACT}

Maintaining the quality of fishery products is something that has to be done immediately as it is related to denial cases of Indonesian fishery products by some receiving countries such as Japan, European countries and USA. Ministry of Maritime Affairs and Fisheries (MMAF) confirm that food safety must be guaranteed throughout the production chain underway to improve the quality of fishery product. Therefore, the MMAF needs to optimize the function of fishing ports as they are the cutting edge and a prime mover in the management and utilization of fish resources and port environment ranging from preproduction, production, processing, and marketing. One of the concepts will be applied by the MMAF is fishing ecoport which adopts the concept of the European Union countries in the management of port environment to increase fisheries production quality by adhering to the principles of biosecurity and traceability product. The Bitung Oceanic Fishing Port (PPS) is become the pilot port for the implementation of this concept.

Keywords: Fishing ecoport, PPS Bitung, Rapert Alert System for Food and Feed (RASFF)

\section{PENDAHULUAN}

Sumberdaya kelautan Indonesia mempunyai peranan penting dan strategis bagi pembangunan nasional baik dari aspek ekonomi, sosial, keamanan dan ekologis. Dengan total luas laut sekitar 3,54 juta $\mathrm{km}^{2}$, yang terdiri dari 0.28 juta $\mathrm{km}^{2}$ perairan kepulauan, 0,28 juta $\mathrm{km}^{2}$ perairan teritorial, dan 2,98 $\mathrm{km}^{2}$ perairan Zona Ekonomi
Eksklusif Indonesia (Pusdatin KKP, 2011), menjadikan Indonesia sebagai negara penting dalam sistem perdagangan dan penyediaan bahan baku pangan hasil laut bagi masyarakat nasional dan internasional. Tercatat sejak periode 2002 hingga 2011, volume dan nilai penerimaan ekspor komoditas perikanan menurut komoditas utama memiliki trend grafik yang meningkat dengan 
capai lebih dari 1,16 juta ton dan US\$ 3.5 juta di tahun 2011 (P2HP KKP, 2012).

Uni Eropa (UE) merupakan salah satu tujuan ekspor komoditas perikanan strategis setelah Amerika Serikat dan Jepang dengan pangsa sekitar 13 persen. Adanya pencabutan larangan masuk produk perikanan budidaya Indonesia ke Eropa (CD 690/2012 menghapus sanksi CD 220/2010) (Pusdatin KKPa, 2012), menjadikan tantangan tersendiri bagi produk perikanan tangkap. Hal ini disebabkan karena negara-negara Uni Eropa mensyaratkan pengetatan aturan sertifikasi produk ekspor perikanan dimana salah satunya adalah adanya sertifikat keberlanjutan terhadap lingkungan (eco-sustainability) yang memenuhi prinsip-prinsip tracebility, biosecurity and cleanliness produk (BKIPM, 2011).

Mempertahankan mutu produk perikanan adalah hal yang urgent terkait adanya beberapa kasus penolakan produk ekspor perikanan Indonesia oleh beberapa negara Eropa seperti Norwegia (Pusdatin $\mathrm{KKPb}$, 2012). Kementerian Kelautan dan Perikanan (KKP) terus meningkatkan kualitas mutu produk perikanan. Bahkan, komitmen itu dituangkan dalam Peraturan Menteri Kelautan dan Perikanan No. 01/Men/2007 yang menegaskan bahwa keamanan pangan harus dijamin sepanjang rantai produksi berlangsung. Dalam kaitan dengan produk perikanan tangkap, KKP perlu mengoptimalkan fungsi pelabuhan perikanan yang merupakan ujung tombak dalam pelayanan masyarakat perikanan baik nasional maupun internasional. Peraturan Menteri Kelautan dan Perikanan No. 08/2012 tentang Kepelabuhanan Perikanan, merupakan landasan hukum tepat untuk menjadikan pelabuhan perikanan sebagai prime mover kegiatan pengelolaan dan pemanfaatan sumberdaya ikan dan lingkungannya mulai dari praproduksi, produksi, pengolahan, dan pemasaran.

Salah satu konsep yang akan diterapkan oleh KKP adalah fishing ecoport yang mengadop konsep negara-negara Uni Eropa dalam pengelolaan lingkungan pelabuhan niaga untuk penerapannya di pelabuhan perikanan Indonesia tujuannya agar produk perikanan yang dihasilkan memiliki kualitas ekspor yang baik dan diterima di negaranegara tujuan. Tulisan ini merupakan bagian dari kegiatan Pre-Feasibility Study of Fishing Ecoport in Indonesia kerjasama antara KKP (Badan
Penelitian dan Pengembangan Kelautan dan Periknan dan Direktorat Jendral Perikanan Tangkap) dan The Agence Française de Dévelopment (AFD), Perancis dengan Pelabuhan Perikanan Samudera (PPS) Bitung dan Pelabuhan Perikanan Nusantara (PPN) Kendari). Tujuan dari tulisan ini diantaranya adalah mendefinisikan kriteria konsep fishing ecoport yang disesuaikan dengan kondisi yang ada di Indonesia dan menentukan pelabuhan perikanan yang akan dijadikan pilot project penerapan konsep fishing ecoport untuk selanjutnya dapat dijadikan role model pengembangan pelabuhan perikanan berwawasan lingkungan di Indonesia.

\section{Konsep Fishing Ecoport dan Landasan Hukumnya}

Meski konsep pelabuhan berwawasan lingkungan sudah muncul pertama kali sejak tahun 90-an dan beberapa pelabuhan niaga/perkapalan telah menerapkan konsep Environmental Management and Sustainability (EMS) (Green Image PortsUSA; Ecoport Network-Europe) (Geocomar, 2012) namun belum ada pelabuhan yang resmi menggunakan istilah ecoport terlebih dalam penerapannya untuk pelabuhan perikanan (fishing port). Akan tetapi, ada beberapa kesamaan harapan yang muncul dari diterapkannya konsep tersebut yaitu mengontrol dan meningkatkan sistem manajemen kepelabuhanan dan kualitas yang tinggi di lingkungan pelabuhan.

Fokus pembahasan Fishing Ecoport diantaranya meliputi :

1. Aspek Kelangsungan Sumberdaya Perikanan (Code of Conduct for Responsible Fisheries/CCRF).

2. Aspek Pembinaan Mutu Hasil Perikanan (Hazard Analysis Critical Control Point/HACCP).

3. Aspek Manajemen Lingkungan (ISO 14001) seperti: Sampah (waste); Kualitas Air, udara, dan tanah; Manajeman sedimentasi; Penimbunan (dredging); Suara (noise); Polusi; Loss of natural habitat; dan Pengaturan volume lalulintas) (Anastasopoulus, et al., 2011).

Landasan hukum penerapan konsep fishing ecoport ini adalah kebijakan Pemerintah melalui Kementerian Kelautan dan Perikanan (KKP) dalam melaksanakan amanat undang-undang 45 tahun 2009 tentang Perikanan Pasal 41 dimana KKP berkewajiban untuk menyelenggarakan dan 
melakukan pembinaan pengelolaan pelabuhan perikanan serta mengikuti ketentuan European Sea Ports Organization (ESPO) diantaranya aspek sampah, kualitas air, udara dan tanah, manajemen sedimentasi, penimbunan, suara, polusi, rusaknya habitat alami, pengaturan volume lalulintas (Darbra, 2005; Ecoports, 2006; Ecoports, 2010; ESPO, 2003; Haskoning, 2009; UNESCAP, 2009). Aspek kualitas air, udara, dan tanah serta polusi sejalan dengan Undang-Undang Nomor 32 tahun 2009 tentang Perlindungan dan Pengelolaan Lingkungan Hidup serta ISO 14001 tentang Lingkungan (Curkovic and Sroufe, 2011).

\section{BAHAN DAN METODE}

Metode yang digunakan pada penelitian ini adalah pendekatan kajian kepustakaan (desk study), survey lapangan (site visit) di Pelabuhan Perikanan Samudera (PPS) terpilih sebagai pilot project untuk penerapan konsep Fishing Ecoport di Indonesia. Adapun parameter yang menjadi perhatian adalah produksi perikanan, kondisi fisik pelabuhan (design and maintenance), fungsi dan layanan pelabuhan (function and services), kebersihan lingkungan pelabuhan (sanitary), keamanan produk (biosecurity, health and environment) dan penggunaan energi (energy saving).

\section{Analisis SWOT dan Analisis Tulang Ikan}

Analisis menggunakan SWOT untuk mengidentifikasi Kekuatan; Kelemahan; Peluang dan Ancaman PPS Bitung akibat fungsi pelabuhan perikanan yang ditetapkan Undang-Undang dan Peraturan Menteri; dan aturan Internasional (IOTC; IUU; CCRF, dll) tidak terlaksana sepenuhnya. Di lain pihak sinergi dan dukungan lintas sektor terkait Era Otonomi Daerah perlu dibangun "corporate culture"; kemitraan Pusat dan Daerah serta mempertimbangkan hukum adat dan/atau Kearifan Lokal.

Adapun pelabuhan perikanan yang menjadi percontohan untuk penerapan konsep fishing ecoport adalah PPS Bitung, Sulawesi Utara. Posisi pelabuhan yang berhadapan langsung dengan pulau Lembeh yang berfungsi sebagai breakwater alam membuat pelabuhan aman dari gangguan angin dan gelombang. Kota Bitung ditetapkan sebagai Kawasan Minapolitan (Keputusan Menteri
Kelautan dan Perikanan Republik Indonesia Nomor KEP.32/MEN/2010 tentang Penetapan Kawasan Minapolitan) merupakan Instrumen pendukung pelaksanaan kegiatan Kemaritiman yang membawa dampak multiplier effect bagi kemajuan masyarakat Kota Bitung.

\section{HASIL DAN PEMBAHASAN}

\subsection{Permasalahan Pengelolaan}

Permasalahan utama dalam pengelolaan pelabuhan perikanan adalah segenap fungsi yang telah ditetapkan dalam Peraturan Menteri Kelautan dan Perikanan nomor 08/MEN/2012 tentang Kepelabuhanan perikanan, apakah sudah sepenuhnya dilaksanakan atau masih ada kendala dalam penerapannya (mengapa tidak berfungsi; dimana kendalanya; siapa yang harus melaksanakan, bagaimana cara meningkatkan pelayanan pelabuhan perikanan, dll). Gambar 1 merupakan fish bone analysis yang mengidentifikasi masalah utama pelabuhan perikanan dan turunan-turunan masalahnya sehingga memudahkan untuk penanganannya.

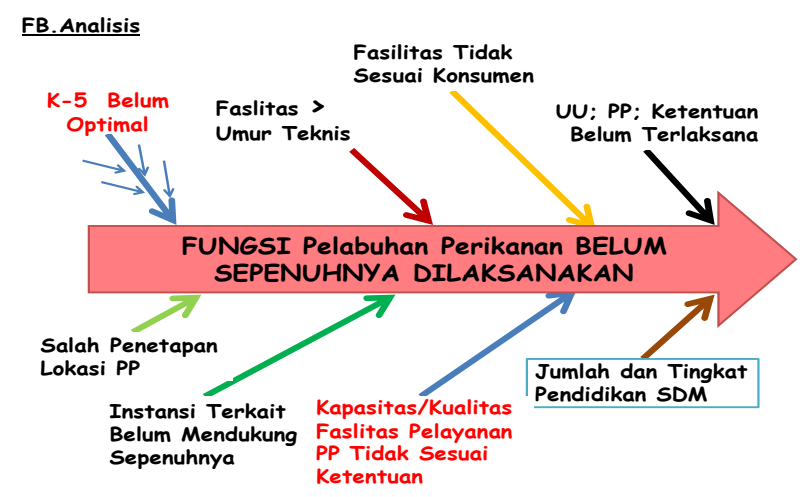

Gambar 1. Analisis tulang ikan

Figure 1. Fish bone analysis

Sumber: Hasil pengolahan data

\subsection{Kondisi Fasilitas dan SDM Pelabuhan Perikanan}

1. Kondisi Fasilitas

- Lahan Pelabuhan: Kebutuhan lahan pelabuhan perikanan samudera Peraturan Menteri No.08/MEN/2012 tentang Kepelabuhanan Perikanan secara teknis sekurang-kurangnya 20 ha; secara faktual 5,7 ha berarti masih dibutuhkan lahan (14,3 ha).

- Kapasitas Dermaga: sekurangnya 300 m dengan kedalaman sekurangnya minus $3 \mathrm{~m}$, 
peruntukannya kapal perikanan > $30 \mathrm{GT}$. Secara faktual panjang $126 \mathrm{~m}$ dengan kedalaman minus 5 meter; sehingga 85\% kapal perikanan masih melakukan bongkar muat di pelabuhan tangkahan, Pelabuhan Umum, Dermaga Angkatan laut.

- Kapasitas Air Bersih: Kebutuhan air sebesar $400 \mathrm{~m}^{3}$ /hari dan kemampuan kapasitas $50 \mathrm{~m}^{3}$ (dibangun PU) dan milik pelabuhan kapasitas $20 \mathrm{~m}^{3}$ sehingga kebutuhan air untuk logistik kapal perikanan disuplai dari luar pelabuhan. Tidak dilakukan pengawasan baku mutu air yang higienis sesuai standard HACCP.

- Kapasitas Daya Listrik: Kapasitas daya listrik 30 KVA untuk operasional kantor dan penerangan jalan dan dermaga pelabuhan, sedang kebutuhan operasional 150 KVA. PLN belum mampu mendukung akibat keterbatasan catu daya listrik.

- Kapasitas instalasi pengolahan air limbah (IPAL): kapasitas $100 \mathrm{~m}^{3}$ menampung limbah buangan dari Tempat Pelelangan Ikan (TPI) saja, sehingga belum melayani menampung/ mengolah limbah industri pengolahan di pelabuhan.

- Ruang Kantor Karyawan: terbatas untuk menampung 93 orang staf (honorer 62 orang/ $66 \%$ ) dengan pendidikan di bawah SLA sehingga suasana kerja kurang nyaman.

\section{Kinerja Pelabuhan Perikanan}

\subsection{Pelayanan Produksi}

a. Dermaga Sarana Bongkar Untuk Kapal Diatas 100 GT hanya mampu menampung satu kapal bobot $>100$ GT dan kapal selesai membongkar ikan langsung mengisi perbekalan; tidak dapat berpindah tempat.

b. Dermaga Produksi untuk kapal 60-100 GT memiliki daya tampung terbatas dan kapal selesai membongkar ikan melakukan pengisian perbekalan (Logistik: Es, air, solar) tidak berpindah tempat ke dermaga labuh; karena dermaga labuh tidak mampu menampung kapal diatas 60-100 GT.

c. Kapal di bawah 60 GT di dekat Tempat Pelelangan Ikan ada jenis perahu ikan disebut "pumpboat" dilengkapi dengan sayap penyeimbang di kiri/kanan perahu sangat mengganggu olah gerak kapal ikan lain karena tidak mau berpindah tempat setelah membongkar hasil tangkapan.

2.2 Dermaga Pelayanan Produksi untuk Suplai Logistik

a. Pengisian air tawar oleh swasta mendatangkan air tawar dari luar pelabuhan perikanan diangkut minibus dan dialirkan dengan pipa ke kapal ikan; keberadaan truk di dermaga mengganggu kegiatan pelayanan membongkar ikan.

b. Pengisian Solar dari SPDB ke kapal ikan berjarak 75 meter dari dermaga produksi ternyata pipanya bocor dibak kontrol, tetesan solar dapat mencemari ikan dan kolam pelabuhan serta dermaga produksi; beresiko timbul kebakaran kapal ikan.

c. Jenis BBM lain adalah Premium (minyak bensin); minyak tanah; dan oli diangkut dengan menggunakan kendaraan roda 4 (truk) yang dibongkar di dermaga sehingga tetesan yang tumpah beresiko kebakaran.

2.3 Pelayanan es disuplai oleh 12 pabrik es swasta berlokasi 100 meter sampai $15 \mathrm{~km}$ di luar PPS Bitung. Pelayanan es untuk kapal ikan diangkut dengan menggunakan truk bak terbuka dan parkir di pinggir dermaga sehingga mengganggu aktivitas.

2.4 Penanganan ikan di TPI dari truk diangkut keranjang yang kotor ditumpahkan ke lantai TPI. Meja dipakai duduk pengguna jasa mengamati ikan yang akan dibeli sambil merokok (ada tanda larangan merokok) dan membuang puntung rokok di lantai TPI. Selesai transaksi, ikan diangkut truk pickup ke pabrik pengolahan dan disimpan dalam bak berisi air laut serta es di TPI diangkut esok hari ke pabrik pengolahan dan pasar ikan lokal. Lantai TPI dibersihkan dengan air kolam pelabuhan yang dihisap dengan pompa air portable. Kualitas air diragukan karena disekitar perahu penuh sampah plastik bekas minuman atau bungkus makanan serta fasilitas MCK perahu/kapal pembuangan kotoran serta tetesan solar dan bbm dari pipa yang bocor langsung ke kolam.

2.5 Kawasan Tambat Labuh sedang proses pembangunan, dan belum sepenuhnya digunakan. Petunjuk penggunaan areal dan larangan bagi pengguna jasa sudah ada. 
Pengawasan di lapangan masih kurang mampu mengatasi pelanggaran.

2.6 Kawasan Industri pengolahan perikanan dan suplai logistik (solar; oli; minyak tanah); perbaikan dan perawatan kapal penangkapan serta kapal motor yang kesemuanya beresiko pencemaran lingkungan karena belum ada instalasi pengolahan limbah (IPAL).

2.7 Tempat Sampah Sementara digunakan untuk menampung berbagai macam sampah dan belum ada pemisahan jenis sampah organik dan anorganik termasuk plastik di lingkungan PPS Bitung.

2.8 SPDN ada 2 unit penyaluran BBM untuk melayani kapal ikan di areal dermaga produksi sudah operasional dan satunya lagi di dekat kawasan tambat labuh kapal ikan sedang persiapan operasi dan penyalurannya belum tertib.

2.9 Kawasan Sosial dengan berbagai fasilitas sosial (parkir; musholla; gereja; pertokoan; kantin/cafe; MCK) masih belum tertata dalam suatu zona, tetapi masih terpencar pada berbagai tempat. Pengguna jasa yang masuk ke kawasan PPS Bitung beraneka ragam kepentingan mulai dari yang hanya ingin tahu; berpariwisata; bisnis sambilan non perikanan sampai pengusaha perikanan.

2.10 Alur Kegiatan di Pelabuhan menyangkut proses pendaratan ikan di dermaga produksi; dermaga tambat labuh untuk pengisian logistik. Pergerakkan kapal ikan ini terhambat keterbatasan dermaga. Lalu lintas kendaraan di darat pergerakkannya belum diatur dengan petunjuk rambu lalu lintas yang jelas, pengawasan lemah kawasan menjadi tidak tertib terutama pada saat aktivitas tinggi. Koordinasi Instansi terkait sudah berjalan tetapi akibat keterbatasan kemampuan dan kapasitas yang dimiliki instansi tersebut (keterbatasan kemampuan PLN menyediakan suplai listrik; dan instansi lain suplai air; suplai BBM; dukungan keamanan; dukungan kebersihan).

\subsection{Aspek Sumberdaya Perikanan}

Pengelolaan sumber daya perikanan di Indonesia masih dianggap "open acces" dan masih terjadi dualisme pengelolaan (Nikijuluw, 2002). Hal tersebut dapat dilihat pada Gambar 2.

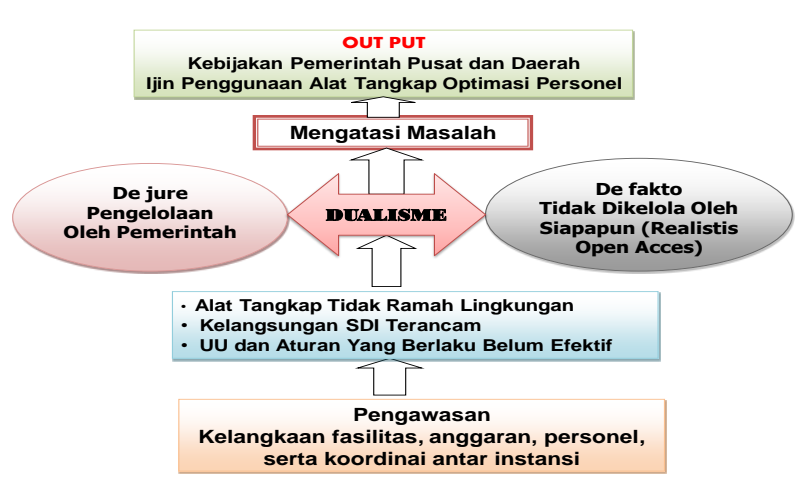

Gambar 2. Pengelolaan sumber daya ikan di pelabuhan perikanan

Figure 2. Management of fish resources in fishing port Sumber: Hasil pengolahan data

Untuk menegaskan bahwa tugas pelayanan pengelolaan sumberdaya perikanan ditetapkan Peraturan Menteri Kelautan dan Perikanan Republik Indonesia Nomor PER.29/MEN/2010 Tentang Perubahan Kedua Atas Peraturan Menteri Kelautan dan Perikanan Nomor PER.06/MEN/2007 Tentang Organisasi dan Tata Kerja Pelabuhan Perikanan dalam rangka meningkatkan pelayanan kepada masyarakat perikanan dan untuk menunjang optimalisasi produksi perikanan serta pengelolaan sumber daya ikan, maka dipandang perlu menyempurnakan Peraturan Menteri Kelautan dan Perikanan Nomor: PER.06/MEN/2007 tentang Organisasi dan Tata Kerja Pelabuhan Perikanan, sebagaimana telah diubah dengan Peraturan Menteri Kelautan dan Perikanan Nomor PER.19/MEN/2008. Perubahan Peraturan Menteri ini harus diterjemahkan dan diberdayakan tindak lanjut implementasinya.

\subsection{Aspek Mutu Hasil Perikanan}

Keberadaan berbagai macam aturan dan ketentuan yang sudah ditetapkan oleh Pemerintah (HACCP) untuk melaksanakan pembinaan mutu perikanan. Peraturan Menteri Kelautan dan Perikanan Republik Indonesia Nomor PER.29/MEN/2010 Tentang Perubahan Kedua Atas Peraturan Menteri Kelautan dan Perikanan Nomor PER.06/MEN/2007 Tentang Organisasi dan Tata Kerja Pelabuhan Perikanan adalah dalam rangka meningkatkan pelayanan kepada masyarakat perikanan dan untuk menunjang optimalisasi produksi perikanan serta pengelolaan sumber daya ikan. Kelemahan menterjemahkan dan mengimplementasikan aturan sebagai akibat 
keterbatasan kemampuan dari staf pengelola pelabuhan perikanan.

\subsection{Aspek Manajemen Lingkungan}

Aspek lingkungan yang sering berhubungan dengan pelabuhan perikanan adalah sampah, kualitas air, udara dan tanah, manajemen sedimentasi, penimbunan, suara, polusi akibat minyak tumpah di kolam pelabuhan, rusaknya habitat alami karena alat tangkap berbahaya, pengaturan volume lalu lintas.

Undang Undang Nomor 18 Tahun 2008 Tentang Pengelolaan Sampah belum sepenuhnya dilaksanakan oleh pengelola pelabuhan perikanan karena faktor keterbatasan (sarana; anggaran; teknologi; lokasi; SDM; dan sederetan keterbatasan lainnya). Pengelolaan perlu dukungan dari instansi terkait; teknologi inovasi penanganan sampah serta dukungan nyata dari pembina PPS Bitung maupun pemerintah Daerah Kota Bitung. Aspek pengelolaan air, baik air tawar untuk konsumsi maupun untuk keperluan lain (mandi, mencuci, bahan baku es, menyimpan ikan dicampur es). Demikian pula air laut untuk kebersihan ikan, menyimpan ikan dengan es, mencuci deck kapal, mencuci lantai; kedua air ini baku mutu harus diawasi.

Keberadaan kapal ikan dan industri pengolahan selain membutuhkan bahan pendukung (BBM untuk energi; bahan campuran hasil olahan); keluaran (kebisingan mesin kapal; bekas oli mesin; sisa industri: asap; limbah cair; bau air/ limbah buangan dan lainnya) kesemuanya harus dikelola sesuai ketentuan termasuk adanya galangan kapal yang menggunakan sistem udara tekanan tinggi sebelum kapal dicat.

Berdasarkan hasil analisis SWOT dan langkah tindak lanjut diperlukan untuk mendukung program eco fishing port terutama aspek sumberdaya perikanan maka untuk PPS Bitung diperlukan:

1. Kebijakan pengembangan penangkapan ikan harus bersamaan dengan pengembangan pengawasan sumberdaya perikanan melalui upaya memperketat penggunaan alat tangkap tidak ramah lingkungan. Kondisi ini didasarkan atas pengamatan di lapangan bahwa terdapat Baby Tuna didaratkan di PPS dengan mutu ikan yang kurang bagus akibat ditangkap dengan alat tangkap yang tidak selektif.

2. Peningkatan pengawasan dapat dilakukan juga melalui ketertiban dalam pencatatan data hasil tangkapan yang didaratkan di PPS sebagai alat pengendali penggunaan alat tangkap yang ramah lingkungan dan selektif terhadap jenis dan ukuran hasil tangkapan yang diperbolehkan.

\section{KESIMPULAN DAN SARAN}

\section{Kesimpulan}

Dari hasil kajian terhadap berbagai aspek terhadap Pelabuhan Perikanan Samudera (PPS) Bitung dapat disimpulkan bahwa:

1. Kinerja PPS Bitung belum sepenuhnya memenuhi ketentuan yang dapat dikategorikan sebagai eco fishing port berbasis blue economy memusatkan perhatian pada biosecurity dan tracebility produk perikanan yang dihasilkan.

2. Ada beberapa kendala yang perlu diatasi dan arahan pengembangan baik aspek kinerja PPS; aspek Manajemen Sumberdaya Perikanan; Aspek Manajemen Mutu; dan Aspek Manajemen Lingkungan yang mengacu pada ISO 14001.

3. Peraturan perundangan yang menjadi payung hukum bagi PPS Bitung untuk pengelolaan kepelabuhanan yang berwawasan lingkungan sudah ada, hanya terkendala dalam tahap implementasi (punishment dan law enforcement) yang menjadi panduan bagi pengelola pelabuhan untuk menerapkan konsep fishing ecoport.

\section{Saran}

Dari hasil peninjauan lapangan di kawasan PPS Bitung dan setelah mendapat data serta informasi dilakukan analisis terhadap kinerja dan kendala kondisi di lapangan, dapat direkomendasikan sebagai berikut:

1. Review kembali Master Plan (rencana Induk) yang sudah ada untuk diimplementasikan secara bertahap dan konsisten.

2. Meningkatkan koordinasi dengan berbagai instansi terkait yang memiliki kepentingan langsung untuk pelayanan kepada masyarakat perikanan (PLN; Pertamina; PDAM; 
Laboratooorium Mutu; KLH; Pemerintah Daerah; stakeholder di kawasan dll).

3. Meningkatkan koordinasi untuk pengawasan terhadap penggunaan alat tangkap dan tindakan yang mengarah kepada pelanggaran IUU Fishing.

4. Guna mengamankan mutu produk perikanan, diperlukan peningkatkan koordinasi untuk pengawasan penanganan produk sejak ditangkap; diangkat $k e$ atas kapal dan diangkut ke pelabuhan; cara menangani ikan di dermaga dan metode handling serta distribusi ikan baik pasar lokal maupun ke kawasan industri.

5. Pengendalian terhadap kondisi lingkungan pelabuhan perikanan ditingkatkan melalui pelaksanaan pengawasan internal; sosialisasi secara berkala kepada Stakeholders; penyediaan fasilitas pengelolaan limbah padat dan cair.

6. Dilakukan kajian kembali terhadap SDM yang terlibat dalam pengelolaan PPS Bitung baik jumlah dan kapasitas serta kualisasi staf untuk mengisi jabatan yang telah ditetapkan untuk Pelabuhan Perikanan Samudera (PPS).

\section{DAFTAR PUSTAKA}

Anastasopoulos, D., Kolios, S. \& Stylios, C. (2011). How will greek ports become green ports? GeoEco-marina, 17/2011.

BKIPM. (2011). Rencana Strategis BKIPM 2011-2014. Badan Karantina Ikan, Pengendalian Mutu dan Keamanan Hasil Perikanan. Kementerian Kelautan dan Perikanan.

Curkovic, S., \& Sroufe, R. (2011). Using ISO 14001 to promote a sustainable supply chain strategy. Business Strategy and the Environment, 20, 7193. DOI: $10.1002 /$ bse.671.

Darbra, R. M., Ronza, A., Stojanovic, T.A., Wooldridge, C., \& Casal, J. (2005). A procedure for identifying significant environmental aspects in sea ports. Marine Pollution Bulletin, 50, 866874. PMid:15946703.

EcoPorts. (2006). The Top-10 Port Environmental Issues. EcoPorts: Brussels. Available at: http://www.ecoports.com/page.ocl?pageid=127.

EcoPorts. (2010). Tool 4: Port Environmental Review System (PERS). EcoPorts: Brussels. Available at: http://www.ecoports.com/page.ocl?pageid=30.

ESPO (European Sea Ports Organisation). (2003). Environmental Code of Practice. ESPO: Brussels.

http://www.espo.be/downloads/archive/85817e8 7-5a24-4c43-b570-146cb7f36b68.pdf.

Geoecomar. (2012). Project Ecoport 8: Enviromental Management of Transborder Corridor Ports Code SEE/A/218/2.2/X.

Haskoning, R. (2009). Green Ports. Available at: http://www.royalhaskoning.co.uk.

Nikijuluw, V. P. H. (2002). Rezim Pengelolaan Sumberdaya Perikanan. Jakarta: Diterbitkan atas kerjasama P3R dengan PT. Pustaka Cidesindo.

P2HP KKP. (2012). Statistik Ekspor Hasil Perikanan 2011. Buku 1. Direktorat Jenderal Pengolahan dan Pemasaran Hasil Perikanan (P2HP). Kementerian Kelautan dan Perikanan.

Pusdatin KKP. (2011). Data Pokok Kelautan dan Perikanan Periode s.d. Oktober 2011. Pusat Data, Statistik dan Informasi Sekretariat Jenderal, Kementerian Kelautan dan Perikanan.

Pusdatin KKPa. (2012). Siaran Pers: Pacu Ekspor, KKP Tingkatkan Mutu dan Keamanan Produk Perikanan. No. B.128/PDSI/HM.301/IX/2012. http://www/kkp/go/id/index.php/arsip/c/8231/PA CU-EKSPOR-KKP-TINGKATKAN-MUTUDANKEAMANAN-PRODUKPERIKANAN/?category_id=

Pusdatin KKPb. (2012). Siaran Pers: Indonesia Norwegia Perluas Kerjasama Bilateral. No.B.156/PDSI/HM.310/XI/2012. http://www.kkp.go.id/index.php/arsip/c/8371/IN DONESIA-NORWEGIA-PERLUAS-KERJASAMABILATERAL/?category_id=34Pemerintah

UNESCAP (United Nations Economic and Social Commission for Asia and the Pacific). (2009). Environmental impacts of port development. United Nations: Bangkok. http://www.unescap.org/ttdw/Publications/TFS pubs/ Pub_1234/pub_1234_ch2.pdf. 